\title{
BEAUTY ELECTIONS IN SLAVONIA: A STUDY OF TRADITIONAL COSTUME COMPETITIONS
}

\section{Marija Gačić}

\begin{abstract}
The article focuses on the phenomenon of traditional costume competitions and interprets its importance for the local community and the contestants. The author analyses the issue of evaluating, selecting, and awarding the best traditional costumes. The research draws on the material of Slavonia, a region in Croatia with a constantly growing trend of traditional costume competitions. The author also emphasises the importance of the role of ethnologists as members of expert committees in the process. The study is based on ethnographic research, discourse analysis of documents related to the contests, and on the author's personal experience, since she has participated in traditional costume competitions in different roles.
\end{abstract}

Keywords: competition, Croatia, ethnologists, selection, Slavonia, traditional costumes

\section{INTRODUCTION}

Beauty contests have been held in Slavonia, the eastern part of Croatia, for almost 80 years now. As early as in 1936, ethnologists recorded this phenomenon within the frame of the first folklore festivals, organised by the Peasant Concord organisation, where different villages competed in the beauty and cleanliness of their costumes. In the same year, 1936, the organisation decided to give the award to a girl with the most beautiful costume (see Bonifačić 2008: 21). Today, the most popular contests are still connected with larger folklore festivals, such as Đakovački vezovi (embroideries of Đakovo), Brodsko kolo (the kolo (dance) of Brod), and Šokačko sijelo (festival of folk heritage) in Županja, eastern Slavonia. Nevertheless, there are a number of independent competitions, often specialised in a certain type of traditional costumes, such as Zimsko spremanje (Winter Wearing) in Antin, which specialises in winter traditional costumes, or Bil me mamo u Kupinu dala (Would You, Mother, Give Me to Kupina) in Kupina, specialising in traditional wedding costumes. These are smaller manifestations of local significance, but they gather a great number of contestants from different parts of Slavonia and Croatia. 
The paper aims to address selected competitions, followed by the analysis and comparison, and to highlight specific and general characteristics of the elections and the roles of the contestants, organisers, and the expert committee. It also endeavours to reveal the role of elections in the festivals that they are a part of, but also in the life of the local community and that of the individuals who apply for these contests.

My analysis is based on the documents that the organisers send to potential competitors. These mainly consist in the invitation letter for potential participants and the application forms. The rules of the contests do not generally exist as a separate document but can be deduced from the questions in the application form, while some restrictions are listed in the invitation letters. Besides that, I have used the data collected during fieldwork in the period from 2007 to 2014 , and by personally participating in some elections in various roles: as a contestant, an organiser, and a member of the expert committee.

In this review I will give short individual descriptions of the competitions, describe the general characteristics, and try to answer questions about why people apply for beauty elections in traditional costumes, what these elections mean to people, what is the role of the traditional costume in contemporary elections, etc.

\section{'BEAUTY ELECTIONS' AS A TERM}

In Slavonia, the term 'beauty elections' is a common name for the competitions in which participants are dressed in traditional costumes and are competing for the title of the most beautiful or the best traditional costume. If one wants to know whether another person is going to watch the final programme of the largest folklore festival in Slavonia, Đakovački vezovi, they usually ask: "Are you going to watch the beauties?" The phrase 'beauty elections' refers to every contest related to traditional costumes, no matter what the exact name of the contest is, or what its theme or ideas are. Croatian ethnologist Branka Uzelac explains the development of the present name for the elections, Đakovački vezovi, from The Most Beautiful Worn Traditional Costume to The Best Worn Traditional Costume: “This way the expression 'beauty election' is avoided as the way of usual shorting of the full name of the show" (Uzelac 2001: 19).

The phrase 'beauty elections' is used from the very beginning of the contests in which the most beautiful traditional costumes were elected, and it points to an important question: what is the best traditional costume?

Contemporary competitions of beauties in traditional costumes are generally known as elections, although they have different titles and they allow 
men to compete as well. The official names of the contests, like The Best Worn Traditional Costume of Slavonia, Baranja and Srijem, or Youth and Beauty of Slavonia, etc., are secondary. This is based on the fact that the official names are used only in printed programmes and posters, and rarely in public speeches and in everyday conversations. The term that is used more frequently is 'election', combined with the name of the town or the village where it is held. In this sense, when speaking about a young man, Mladen Seletković, from the village of Donji Andrijevci, who participated in The Winter Wearing contest in Antin, one would say that he "went to election in Antin". So there is the election in Stari Mikanovci, the election in Slavonski Brod, the election in Trnjani, the election in Županja, the election in Đakovo, etc. Considering all that, in this article I will also use the term 'election', but the terms 'contest' and 'competition' are also used as synonyms, because all the elections are structured as contests and competitions.

\section{WHAT DO BEAUTY ELECTIONS LOOK LIKE?}

In Slavonia, almost every village has its own folklore festival and a certain kind of traditional costume election. Here I discuss seven contests with the longest history, like those in Đakovo and in Stari Mikanovci, established in the 1960s, and those specialised in a certain kind of traditional costumes, like winter costumes in Antin (est. in 1999) or bridal costumes in Kupina (est. in 2011). What they have in common is a two-part structure of the competition. The first part is a presentation in front of the expert committee, and the second takes place in front of a wider audience. The contests are held throughout the year, except for the time of the Great Lent and Advent. Some of them are a part of bigger traditional festivals that are held at the same time every year, and some of them are independent programmes, with their own dates (Saturday or Sunday) during the year. The date of the contests can be changed, as some of them are held during the Shrovetide that depends on the date of Easter. Others are not connected to specific holidays but try to keep the same date because they strive towards the title of traditionally held programmes.

The contests I am analysing in this article are the following:

1. The Best Worn Traditional Costume ${ }^{1}$ is the central part of the final show of one of the largest folklore festivals in Croatia, Đakovački vezovi. It was established in 1967. The festival is always held during the last week of June and the first week of July. Until now it has changed its name and rules several times. For the first three years only unmarried women were allowed to compete. In 1970 the competition was opened to married women as well, and in 2002 
the possibility of competing also opened up for men. The potential competitors have to fill in the application form before the competition. On the day of the competition they are asked to present their costume and show their knowledge about it in front of an expert committee, and in the evening in the central park in Đakovo, in front of numerous audiences. The expert committee consists of three ethnologists. They give three awards for the best costumes (the first, the second, and the third prize) in three categories: men, married women, and girls. Along with that, the Mayor of Đakovo gives his own prize to a girl that he thinks is the most beautiful, and she is proclaimed the most beautiful girl in a traditional costume. That overshadows all the other winners selected by the ethnologists.

2. The contest called The Youth and the Beauty of Slavonia was founded in 1968 in the village of Stari Mikanovci.

From the very beginning, there were rules defining who can compete and under what conditions. Competitors can be neither younger than 16 nor older than 30 years of age. They need to possess good knowledge of the traditional costume that they are wearing, they need to know for what occasion which sort of traditional costume is intended, how it is made, and the traditional costume should originate from the village where the competitor lives, etc. (Frković et al. 1997: 52)

Besides questions about traditional costumes, the application form contains questions about competitors' everyday life, such as: "Do you do some kind of traditional handicraft?" (Application Form, Stari Mikanovci 2015). ${ }^{2}$ The expert committee consists of three ethnologists. They give three prizes in the same three categories as in Đakovo. The competition takes place on the last Saturday in February.

3. The Flower of $\check{S} k_{c i} i^{3}$ is the contest of girls from 16 to 25 years of age. They have to be from the region in which the Šokci live (Slavonia, Baranja, Srijem, Bačka). The election is the final show of the carnival festival Šokačko sijelo, which lasts throughout the last two weeks of the Shrovetide period ${ }^{4}$ in the town of Županja. The members of the expert committee are: an ethnologist, the mayor, and one or two sponsors. They give three awards. The first awarded girl is conferred the title of the Flower of Šokci.

4. The Election of the Most Beautiful Croatian Girl in a Traditional Costume is the final show of the oldest Croatian folklore festival, Brodsko kolo, in the town of Slavonski Brod. In this election girls from all over Croatia can compete. The expert committee has several members: an ethnologist, the director of the 


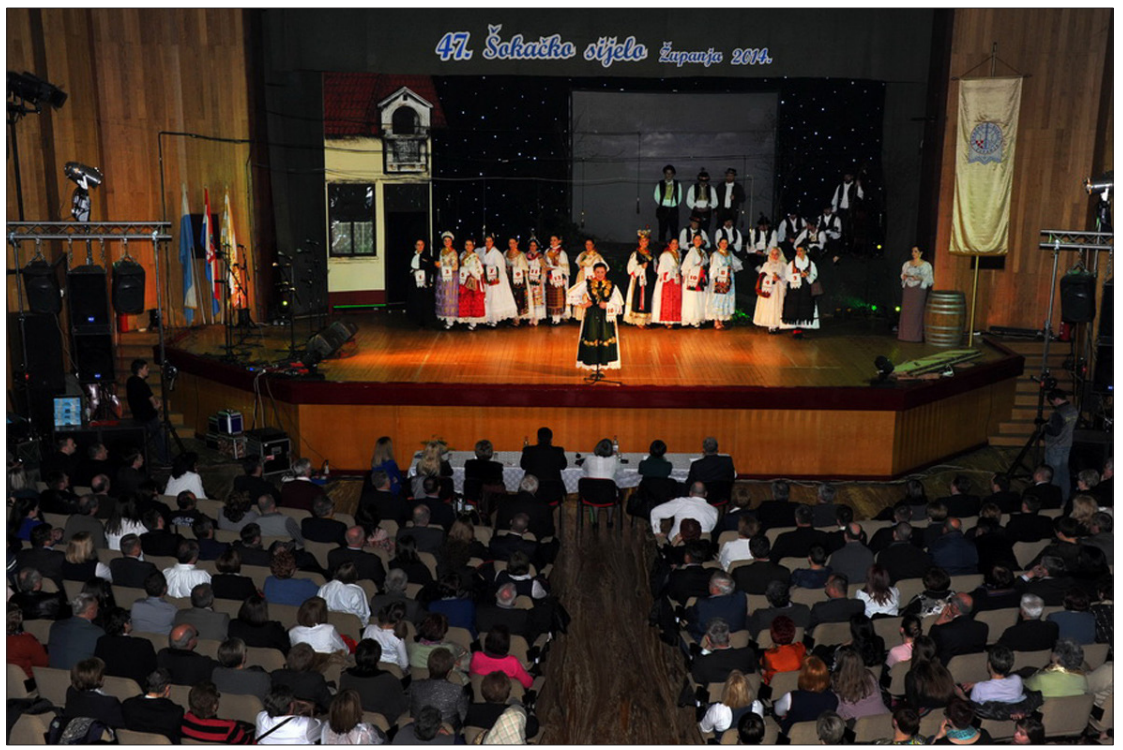

Figure 1. The audience, expert committee, and the contestants at the Flower of Šokci contest in Županja. Photograph from Glas Slavonije 2014 (http: / / www.glas-slavonije. hr/galerija/216/Sokacki-cvit-2014/7).

local tourist board, the festival director, and so on, depending on the organisers' wishes every year. They give three awards. The first awarded girl is proclaimed to be the most beautiful Croatian girl in a traditional costume. The event takes place every year, on the second Sunday of June.

5. The Winter Wearing contest has been held in the village of Antin since 1999, as an independent programme. The competitors (female and male) must wear traditional winter costumes. The expert committee has three members, all of them ethnologists or ethnology students. They hand out three awards in three categories: men, married women, and girls. The election takes place every year, on the third Saturday in January.

6. Would You, Mother, Give Me to Kupina is a specialised election that focuses only on brides in traditional costumes; yet, it refers to a wider circle of wedding customs. It was established in 2011 and takes place on the third Saturday of October. It is an annual gathering of a local folklore group in the village of Kupina. The title is a verse from a traditional local song. The expert committee is comprised of three ethnologists, and they give three awards to the best brides. 
7. Renewing Our Heritage: The Show of Reconstructed Croatian Traditional Costumes was established in 2011 in the village of Trnjani. The date of the event was changed by the organisers from the third Sunday in October, when it was held for the first three years, to the last Saturday of September, because in September it is still warm enough and there is no need to turn the heating on. In this competition only newly made costumes based on traditional patterns can compete. The award does not go to the person who is wearing the costume but to the person who made it. The event is organised by a local folklore group and the Workshop and Traditional Costumes Lending Department - an institution in Zagreb that is involved in the reconstruction of traditional costumes. Members of the expert committee are four ethnologists. They give three awards for the best reconstructed traditional costumes, one award for the best stage presentation, and commendations for a successful reconstruction.

There is a difference between the elections that are a part of a bigger event and those that are organised as independent programmes. The former always occupy a central place in the festival, while the independent ones are organised like small festivals. However, formally all of the elections function in the same way: a few months or weeks before, there is a public invitation for applications, or the organisers directly call the potential contestants. Filling in the application form, different for every competition, is an imperative part of the application process. In the application form every contestant has to fill in the basic information about himself or herself and about his or her traditional costume. The question related to the origins and the age of the costume is obligatory, as well as the one defining all the parts of the costume. Only in Renewing Our Heritage contest there is a space for information about the person who made the costume, and in The Flower of Šokci one is asked to fill in the information about the person who made the traditional hairdo. ${ }^{5}$ The contestants send the application forms to organisers, who forward them to the expert committee. As a rule, the expert committee consists of three members, mainly ethnologists. On the day of the competition they spend a few hours talking to the contestants. They evaluate, rank, and decide about the awards on the basis of the elements of the competition. 


\section{PUBLIC PRESENTATION OF THE CONTESTANTS AND TRADITIONAL COSTUMES}

After presenting the traditional costume to the expert committee, there is a show that is held in front of the audience. It includes the public presentation of the contestants with the narrative about the traditional costumes they are wearing. This is often accompanied by humorous and lascivious comments by the official presenter or by the contestant himself or herself. The contestants present their costumes by emphasising some particular parts and traditional techniques of making and decorating the traditional costume. The public presentation is often shaped like a story that deals with a certain segment of folk life that the traditional costume evokes. The traditional costume is, thus, placed in the usage context. For instance, in 2010 at the election in Antin, a young man was wearing a winter traditional costume and a torch in one hand. He talked about the old way of celebrating Christmas, when people were coming from their cottages ${ }^{6}$ to the village to celebrate the Midnight Mass. He was dressed in an appropriate way, and had an additional object (a torch), but it was his story that provided his presentation of the traditional costume with the desired context.

The public presentation is a complex programme. The contestants' presentations dynamically alternate with those of local bands, playing traditional musical instruments, folklore groups, traditional singing groups, comedians and folk theatre groups that stage humorous plays related to traditional life, etc. The elections differ from each other in the way the presentation of the traditional costume is carried out. At some elections contestants are allowed to talk about the folk costume themselves: how they are dressed, where they would go dressed like that, why they are carrying some additional objects - all these elements are shaped into a story connected to traditional life. This is the case with the election in Stari Mikanovci, Antin, and sometimes in Đakovo, depending on the scenario. Other elections allow this kind of presentation only in front of the expert committee, while in the public presentation, in front of the audience, a presenter reads all the information about them, like at the elections in Slavonski Brod and Trnjani.

The age of the traditional costume is often highlighted. The older traditional costumes are valued more highly. The age of "a hundred years" is a typical formulation that is emphasised at all elections, except at the Renewing Our Heritage, where only newly made costumes are allowed to compete.

The expert committee makes the decision about the winner before the public presentation, but it is kept a secret until the very end because of the suspense and drama effect created for the audience and contestants. 


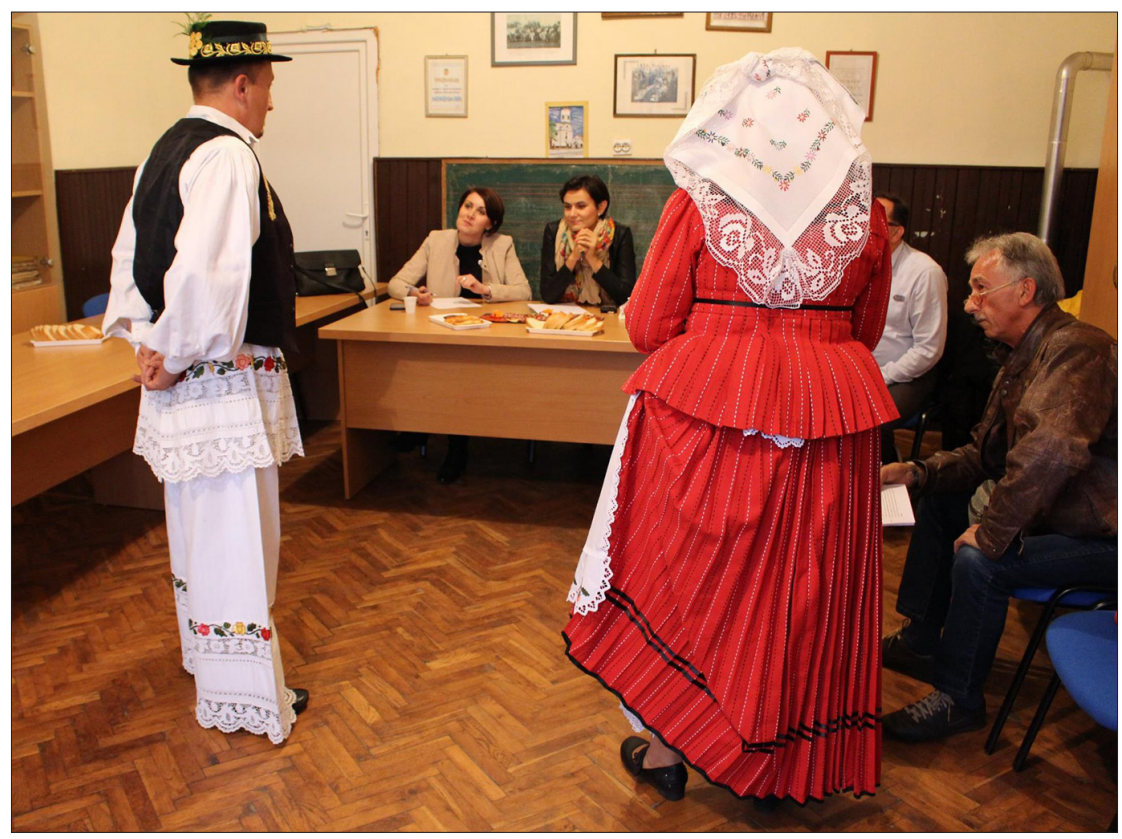

Figure 2. The contestants are presenting newly made traditional costumes in front of the expert committee in Trnjani. Photograph by Bojana Poljaković 2015.

Apart from such contests, there are those that are part of gatherings of local folklore groups, for example, the election in Kupina. The evaluation and presentation of the contestants take place in front of the audience, and the decision about the winner is made during a musical interlude. There is no stage and official show. The election is a part of a party, and it takes place on the dancing floor. No matter what the differences, all the elections have a similar structure. The expert committee has the leading role in making the decision of the winner, but the most important part of the elections for the contestants and the audience is the public presentation. It is shaped like a show with the main goal of entertaining the audience.

\section{THE IMPORTANCE OF THE ELECTIONS}

The common elements of all the elections are competition/evaluation and representation. It is important to highlight the fact that all of the elections function on the basis of fluid, in some cases even non-existing, rules. Each expert committee 
knows what to evaluate, but there are neither written instructions defining the rules for a certain contest, nor a universal document with instructions for the evaluation of traditional costumes in general. This means that every committee, individually gathered for an election, makes its own implicit criteria on the spot. Those criteria are based on certain interrelations between traditional costumes applied for a certain election. The final decision is always based on the comparison of all participant costumes. In most of the elections the older traditional costumes have an advantage. However, more precise information about the age of the traditional costume is rarely given, since the contestants mostly define it as "(more than) a hundred years". Ethnologists in most cases know how to estimate the approximate age of the traditional costume by analysing motives, techniques, and materials. But, on the other hand, it does not mean that the oldest traditional costume at the elections will certainly win. Furthermore, the traditional costumes are informally divided into two categories: festive and working costumes. Traditional festive costumes are usually more decorated and have more chance of winning. But that is not a rule either, because every selection sends a message. If, for example, one year the winning traditional costume is festive, next year, at the same election, there will be more festive costumes, but then the committee can decide to award a working costume to send a message about the importance of protecting the traditional costumes that are in some way neglected. These

Figure 3. A contestant holding an apple and a candle while presenting herself and the traditional costume she is wearing at the Would You, Mother, Give Me to Kupina election of the most beautiful bride in traditional costume in Kupina. Photograph from Šokački portal 2013 (https: / / www.facebook.com / sokackiport / photos / a.39155464 0915021.83082 .15207949486253 $8 / 391556984248120 /$ ?type $=3 \& t$ heater).

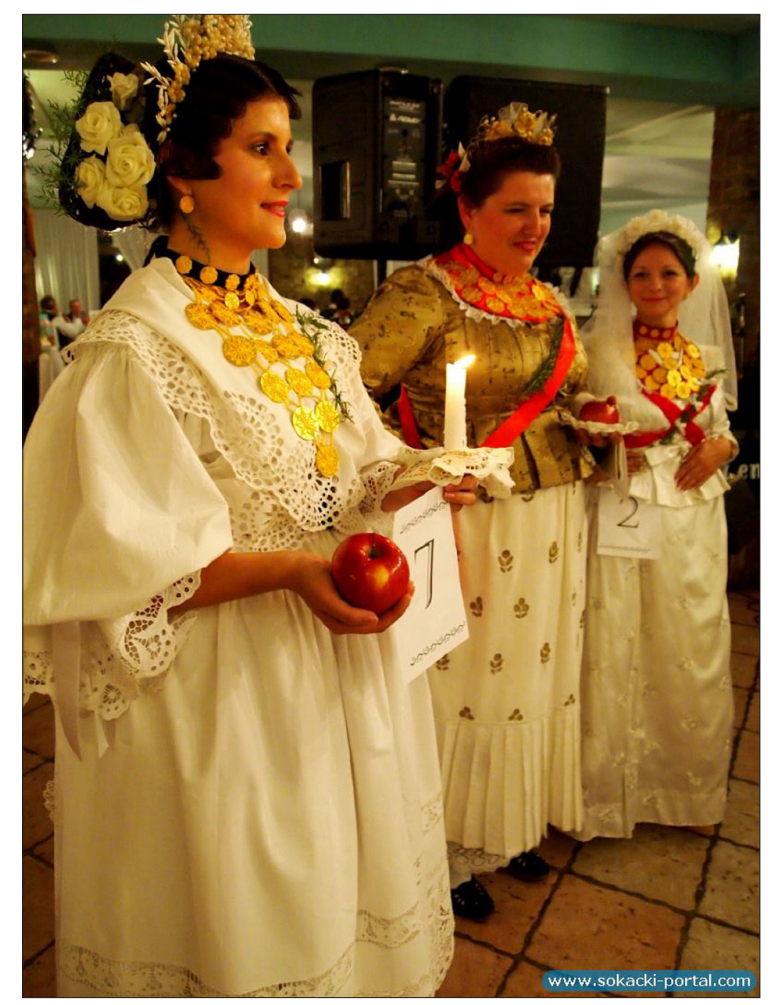


elements are not listed in invitation letters or application forms, but in the same documents we can find expressions like "expert criteria", "aesthetic", or "traditional criteria" (Application Form for The Best Worn Traditional Costume 2015). Since the mentioned criteria are not explained in more detail, the problem of evaluating traditional costumes and selecting the best one can well be understood. It is the easiest for the election of Renewing Our Heritage to arrive at the solution, since it chooses among newly made costumes only, that is, those that are most similar to the originals. Here the expert committee can determine if something is made the way it is made in the village from which that reconstructed traditional costume originates.

In other elections, where only 'original' traditional costumes are allowed to compete, the basis for the evaluation and awarding is hard to find. In these contests the story, that is, the context that the contestants evoke, plays a very significant role.

If the story is humorous (like the story from the election in Đakovo in 2013, where a young married woman came to the stage and said that she had come from the next village on foot, because her husband got drunk and was sleeping in the carriage), the possibility of getting an award is bigger. Although her costume was not so festive, or lavishly decorated, she had a better chance to get an award, based on the story she told. So, there are no rules regulating what kind of traditional costumes are given awards. On the other hand, it is problematic to define the best traditional costume as there is no description of it: what it looks like, what kind of decorations it has, what materials are used, etc.

My experience of working on expert committees tells me that the committees always try to find a solution when proclaiming the best traditional costumes which will justify the committee's expertise and achieve a balance in relation to other elections held during the year. However, the tendency of organisers and contestants is to present the costumes that have not been seen before. That is why, in the last few years, there has been a growing number of collectors who, due to their own diligent collecting of traditional costumes, have expanded their collections and obtained some rare pieces. This leads us to an important question: How is it possible to include in the same category traditional costumes from old chests, costumes that are family inheritance (a granddaughter with no modelling experience wearing her grandmother's costumes), and the ones from the collection of a collector, who will dress a beautiful girl from the next village (thereby carefully removing nail polish and putting on some light makeup)? By preparing the contestants for the election, we discover that, although the rules are not so specific, the contestants and the audience are aware of some kind of rules. In that case, nail polish cannot be compatible with traditional costumes, because it is a sign of modernity. While wearing a traditional costume and 
presenting it at the elections, contestants strive for authenticity and presentation as close as possible to tradition. But if the person is wearing his or her own traditional costume, they represent themselves, their region, village, and heritage. An element that connects all the beauty elections is the contestants' wish to present their identity through traditional costumes. In this manner, I participated in the election in Đakovo and stood in my traditional costume from early afternoon until midnight, trying to show to all the people in the audience the traditional costume from my village, with a strong conviction that my traditional costume was the best. ${ }^{7}$

I can conclude that the elections are an important part of a contemporary public presentation of traditional costumes but also an indication of keeping alive one's tradition and expressing one's identity. Also, the importance of ethnologists as experts in the field is clearly expressed.

\section{PROBLEMS WITH THE ELECTION OF TRADITIONAL COSTUMES}

When analysing the characteristics of the elections, I found several problematic moments. Since in the application form one of the requirements is to define the traditional costume as original or reconstructed (Application Form for the election of The Flower of Šokci in Županja, 2015), one can conclude that it is one of the criteria. Yet, here we can find a connection with the problem of canonisation of traditional costumes. It points to a clear dichotomy between traditional and modern, about which Croatian ethnologist Vjera Bonifačić wrote as follows:

There has been a lot of discussion among scholars and museologists in Europe and North America concerning the preoccupation with selected older pieces of traditional costumes that are defined as traditional and valuated as 'original' or 'authentic', as well as concerning the neglecting of 'inauthentic' peasant clothing that continued to change in the course of the 20th century. (Bonifačić 2008: 10)

Along with this problem, I have raised the question of determining the age of traditional costumes, which is information required in all the application forms. It does not say anywhere whether the older costumes get more points and have more chance of winning the contest than the newer ones. Today's implicit preference of awarding older costumes at the elections originates in the time of activities of the organisation Peasant Concord and its folklore festivals. The peasants were encouraged to revitalise the home production of natural materials and traditional costumes: "A publication of Peasant Concord reveals 


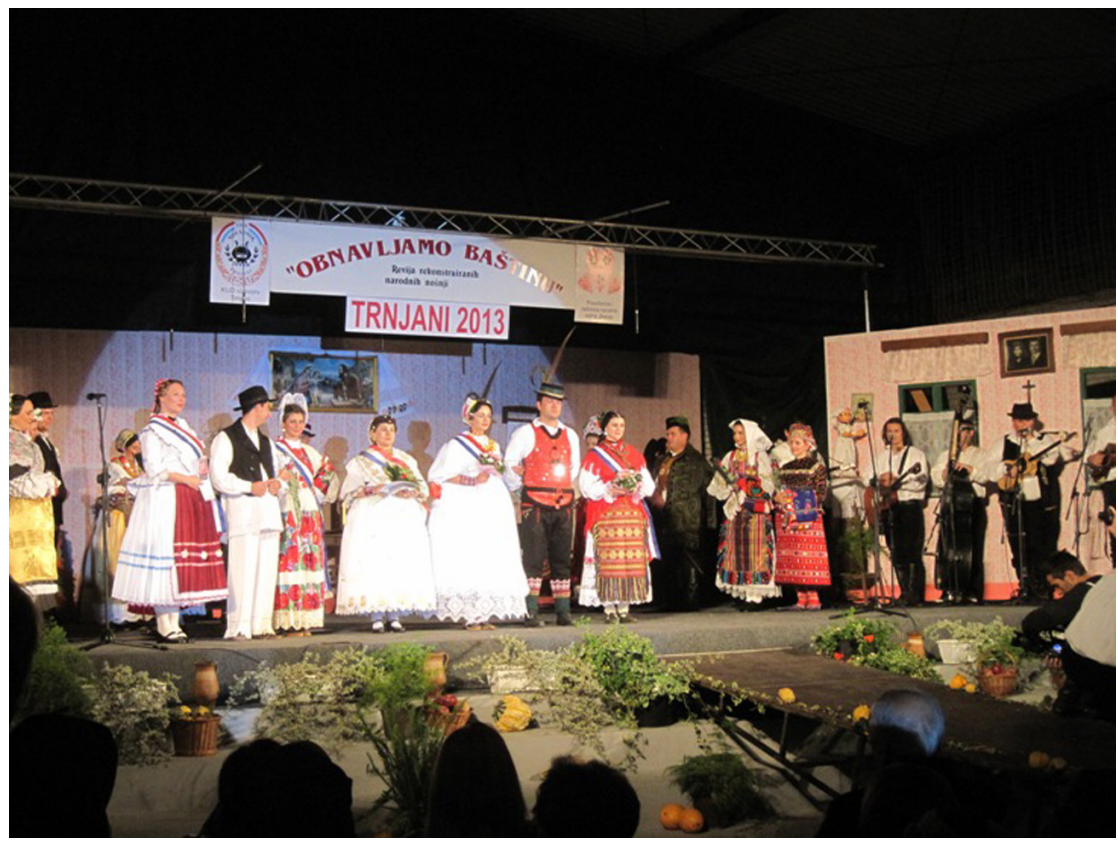

Figure 4. The winning contestants at the Renewing our Heritage contest in Trnjani. Photograph by Zvonimir Ilić 2013.

that there was a pressure on women to go back to making older, hand-made traditional costumes and textiles" (Bonifačić 2008: 21). Even today we can still find the attitude that the older is more valuable.

In application forms it is necessary to explain how the contestants are supposed to present themselves at the election. In every application form requiring that answer, there is the preposition 'as'. A contestant can apply "as a girl", "as a married woman" or "as an unmarried man". The preposition 'as' presupposes the role that the person will play firstly in front of the expert committee, and secondly on the stage in front of the audience, dressed in an appropriate traditional costume. Yet, there is an interesting example of disqualification at the election in Stari Mikanovci, which took place in 2014. An unmarried young woman applied for the election in a role of a married woman, wearing the appropriate traditional costume. She was disqualified because in real life she was not married. This was an act that showed the intention of emphasising the seriousness of the election. However, it is interesting that the year before there had been a divorced woman dressed like a young married woman among the contestants. She was not eliminated from the contest. So, my question is: 
if the presentation at the election in Stari Mikanovci is a performance, as it is pointed out in the application form, why is it connected with real life outside the stage? Here the border between the stage and real life is even more unclear as the questions refer to contestants' private life, regarding private activities connected to 'traditional life'. But it is not clear what kind of activities these are, and how they affect the decision made about the winner.

A specific part of all the invitation letters and application forms is connected to the expert committee/judges. The members of the expert committee are never stated by name; some documents only disclose that the judges are experts, i.e. ethnologists. However, the invitation letters and application forms suggest who the judges could be. The contestants have that in mind while filling in the application form and formulate their answers according to that.

My experience of working on the expert committees is slightly different. The committee consists of at least three people, and not all of them have to be ethnologists - the composition depends on the organiser. Besides ethnologists, the judges can be local or regional politicians, important sponsors, mayors, and so on. Every member of the committee has his or her own attitudes, opinions, and experience related to traditional costumes that they try to implement in the activities that they are engaged in. The decision on the prizes is often a result of negotiations, stressing the judges' own impressions that are finally shaped into a unique decision of the expert committee. Working on this kind of committees is unrewarding because of the lack of rules. Even if the rules of the competition are elaborated, like in the Renewing Our Heritage contest, the judges always bear in mind the message that the selection will send. This part of the beauty elections is indeed an effort of ethnologists to reconcile their own attitudes with the knowledge about traditional costumes, expectations of the audience and organisers, and often with the expectations of the sponsors, local government representatives, and others.

No matter what the attitude of the judges is, ethnologists have a strong position among them and they have to fulfil the expectations of the contestants and the audience, as it is commonly believed that every ethnologist knows everything about traditional costumes and folklore. Despite that, I allow the possibility of unaffected elections if the judges were less of the experts or totally non-ethnologists, as the fun role of the elections is very present. The elections do not depend only on the opinion of the ethnologists on the expert committee, but on the wish of the people to compete.

Announcing the winners is the most important moment of the elections. Although the audience does not participate in the selection process, after proclaiming the winners people from the audience comment on the judges' decision and express their own opinions on it. One can hear people discussing whether 
the award went to the contestants who deserved it or it should go to someone else. This is especially interesting because the rules of the competitions, if they were to exist, are not available to the general public, but only to the contestants and committee members. Nevertheless, the audience has its own system of evaluating and 'awarding'.

\section{CONCLUSION}

Today beauty elections are highly popular in Slavonia and new ones are established every year. This paper covers only a certain number of the elections for the sake of emphasising particular characteristics and problems. The analysis of the basic features of the elections shows that there are some common elements: competition, dichotomy between the old and the new, putting the traditional costume in a context narrating the story related to tradition, an expert committee, etc. There is also a significant fun factor included, but the beauty elections are complex shows that involve traditional music, humorous plays, and competitive spirit, and attract a great number of people - the contestants and the audience - and not only for fun. The other possible reason for the elections' popularity is that people need to present themselves publicly, and need to be acknowledged for their own heritage.

There is the issue of non-existing rules, but the system of the elections functions anyway, because contestants present themselves and the traditional costume from their village. They firmly believe that their costume is the most beautiful. The audience carefully follows the programme and identifies themselves with the contestants but also with judges, because they have their own unofficial 'awards' for 'the most beautiful' traditional costume. These are not actual awards, but the public opinion about who are actually supposed to get the main prize.

The increasing number of the collectors who also take part in the contests by showing their traditional costumes indicates that these elections are the only public place where a person can get some acknowledgment for the traditional costume they possess. The same goes for the traditional costumes from family collections: the traditional costumes do not function the same way as they did 60 years ago, when it meant something in a local community if a girl changed her hair style or if she had abundant jewellery. The beauty elections are the only contemporary events where people can deserve recognition for their family inheritance or for the good choice while shopping in someone's old wardrobe. ${ }^{8}$

The role of ethnologists is important in this context, especially because the evaluating and selecting of 'the best' traditional costume is highly problematic. 
People respect the opinion of the experts and by that they put big responsibility on ethnologists, but they also have great expectations. Fortunately, ethnologists are aware of that, and in most cases they are very careful when proclaiming 'the best' traditional costumes.

\section{NOTES}

1 None of the elections has an English version of the title. All the English titles are translated by the author.

2 Application forms are kept in the author's personal archive.

3 The Šokci consider themselves to be the original inhabitants of the region of Slavonia.

4 Shrovetide activities in Slavonia start after the New Year celebration and last until Ash Wednesday. The activities are comprised of carnival festivals, different costume parties, traditional Shrovetide horse riding ceremonies, etc.

5 Both application forms are available from the author on request.

6 The cottage is literal translation of the Croatian term koleba or stan, meaning a relocated small residential building and outbuildings with livestock outside the village. Family members used to take turns in living at these places and during big holidays they came to the village to attend church. Each bigger family in the village had their own cottage outside the village.

7 In 2007, as a high school student, I participated in the election in Đakovo, wearing the traditional costume of my village, Donji Andrijevci. I presented a story about taking food to the church for blessing on Holy Saturday.

8 Most collectors buy traditional costumes from old people, directly from their wardrobe or an old chest, so I use the image of shopping. Beauty elections are the only chance of public acknowledgment for collectors who have bought something valuable.

\section{REFERENCES}

Bonifačić, Vjera 2008. Etnološka istraživanja i kanonizacija “izvornih" narodnih nošnji u Hrvatskoj 1930-ih. [Ethnological Research and Canonisation of Autochtonous Folk Costumes in Croatia during the 1930s.] Etnološka istraživanja, Vol. 12/13, pp. 9-27. Available at http://hrcak.srce.hr/index.php?show=clanak\&id_clanak_ jezik=58068, last accessed on September 23, 2016.

Frković, Šimo et al. 1997. Tebi, Slavonijo: Tri desetljeća KUD-a "Šokadija" i priredbe "Mladost i ljepota Slavonije" Stari Mikanovci. [To You, Slavonia: Three Decades of the Folk Group "Shokadija" and the Show "Youth and Beauty of Slavonia", Stari Mrkovci.] Vinkovci: Privlačica. 
Uzelac, Branka 2001. Etnološka osobitosti priredbe "Najbolje nošeno narodno ruho". [Ethnological Specific Features of the Show "The Best Folk Costumes".] In: Mirko Ćurić (ed.) Revija 35. Đakovačkih vezova. Đakovo: Turistička zajednica grada Đakova, p. 19.

\section{MANUSCRIPT SOURCES}

Pozivno pismo manifestacije "Obnavljamo baštinu - revije rekonstruiranih narodnih nošnji” 2014. [Invitation Letter for the Manifestation Renewing Our Heritage Show of the Reconstructed Traditional Costumes.] Zagreb.

Poziv za priredbu "Mladost i ljepota Slavonije" 2014. [Invitation for the Show Youth and Beauty of Slavonia.] Stari Mikanovci.

Poziv za priredbu "Zimsko spremanje" u Antinu 2015. [The Invitation to the Show The Winter Wearing in Antin.] Antin.

Poziv za sudjelovanje na izboru najljepše mladenke u narodnom ruhu u sklopu šokačke večere... Bil me mamo u Kupinu dala... 2014. [Invitation for Participating in the Election of the Most Beautiful Bride in Traditional Costume as a Part of šokačka dinner... Would You, Mother, Give Me to Kupina...] Kupina.

Pravila natjecanja (Šokački cvit) 2015. [Rules of the Competition (The Flower of Šokci).] Županja.

Prijava za sudjelovanje na Reviji hrvatskih narodnih nošnji i Izboru najljepše Hrvatice u narodnoj nošnji na 51. Brodskom kolu 2015. u Slavonskom Brodu 14. lipnja 2015. [Application for Participating in the Show of Croatian Traditional Costumes and The Election of the Most Beautiful Croatian Girl in Traditional Costume on the 51st Brodsko Kolo Festival 2015.] Slavonski Brod.

Prijavnica za izbor "Najljepše nošeno narodno ruho" 2015. [Application Form for the Election of The Best Worn Traditional Costume.] Đakovo.

Prijavnica za manifestaciju "Obnavljamo baštinu" reviju rekonstruiranih narodnih nošnji 2014. [Application Form for the Manifestation Renewing Our Heritage - Show of the Reconstructed Traditional Costumes.] Zagreb.

Prijavnica za sudjelovanje na izboru najljepše mladenke u narodnom ruhu u sklopu šokačke večere... Bil me mamo u Kupinu dala... 2014. [The Application Form for Participating in the Election of the Most Beautiful Bride in Traditional Costume as a Part of šokačka dinner... Would You, Mother, Give Me to Kupina...] Kupina.

Prijavni list za priredbu "Zimsko spremanje" u Antinu 2015. [The Application Form for the Show The Winter Wearing in Antin.] Antin.

Prijavni list za sudionike u reviji priredbe "Mladost i ljepota Slavonije 2014". [Application Form for the Participants in the Election of the Show Youth and Beauty of Slavonia 2014.] Stari Mikanovci.

Propozicije manifestacije "Obnavljamo baštinu" 2014. [Rules of the Manifestation Renewing Our Heritage.] Zagreb.

"Šokački cvit" Prijavnica. [The Flower of Šokci Application Form.] 2015. Županja.

Upute natjecateljicama izbora za najljepšu mladu 2014. [Instructions for the Contestants Applied for the Election of the Most Beautiful Bride.] Kupina. 